\title{
COMMENTARY
}

\section{Unravelling the enigma of SAR11}

\author{
Ian Joint
}

The ISME Journal (2008) 2, 455-456; doi:10.1038/ ismej.2008.30; published online 20 March 2008

Since the earliest application of rRNA sequence analysis by Giovannoni et al. (1990), we have come to expect the dominance of SAR11 sequences in marine samples. They appear to be everywhere and SAR11 accounts for a very significant proportion of bacterioplankton in both surface and deep water (Morris et al., 2002). This apparent ubiquity raises interesting questions about how a single lineage can be suited to so many marine provinces-with very different conditions of overall productivity, temperature and nutrient concentrations.

The isolation of the first cultures of SAR11 (Rappé et al., 2002) not only provided the opportunity to give a name to SAR11 (Candidatus Pelagibacter ubique) but also increased the number of unanswered questions. It turned out that SAR11 is an extremely small bacterium, subsequently suggested to have the smallest genome of any free-living bacterium (Giovannoni et al., 2005). In contrast to commensal bacteria that obtain complex molecules directly from a host, SAR11 is a free-living bacterium that has to rely on the very dilute concentrations of organic substrates that are present in seawater. This might be expected to be a particular challenge for a bacterium with a genome of only $1.3 \mathrm{Mb}$. However, SAR11 appeared to have all of the basic functions that might be expected of a free-living bacterium (Giovannoni et al., 2005), such as the complete biosynthetic pathways for all 20 amino acids.

Now Tripp et al. (2008) have suggested that 'Cand. P. ubique' does not have quite a complete complement of metabolic functions; indeed it requires a source of exogenous reduced sulphur compounds. Analysis of complete genome sequences from two 'Cand. P. ubique' strains indicates that genes for assimilatory sulphate reduction are absent. Reduced sulphur is required for growth, and Tripp et al. (2008) suggest that this can be derived from dissolved compounds, such as the sulphur-containing amino acid, methionine, and from dimethylsulphoniopropionate (DMSP). The latter can be a significant sulphur-source because it is used as an osmoregulant by many marine phytoplankton, particularly bloom-forming species, such as coccolithophores. Growth of laboratory cultures of 'Cand. P. ubique' was enhanced by the addition of both substrates, but the resulting cell densities remained

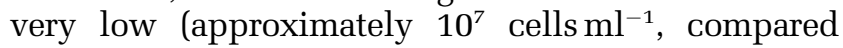

with $1.1 \times 10^{6} \mathrm{ml}^{-1}$ for growth in unmodified seawater). Experiments on DMSP as substrate showed that there was sufficient incorporation of sulphur to meet requirement of the cell and that only $7 \%$ of the carbon requirement could be met from DMSP. The enhanced yield did not result from the carbon in DMSP but was probably due to meeting the needs of the cell for reduced sulphur. These findings help to explain how a free-living bacterium can survive with a small genome-it has reduced anabolism, particularly reductive steps, to a minimum. The disadvantage is that the cell may then be involved in intense competition for a resource that may be limiting.

How does this finding translate to what we know about reduced sulphur compounds in the sea? Using the uptake of ${ }^{35} \mathrm{~S}$ methionine as a measure of bacterial production, Mary et al. (2006) found that SAR11 actively took up methionine throughout a long transect of the North and South Atlantic. They interpreted this uptake as evidence that SAR11, and other low-nucleic-acid bacterioplankton (as determined by flow cytometry), were active and not dormant. These results are entirely consistent with the suggestion of Tripp et al. (2008) that SAR11 cells require a reduced sulphur source. What about information from studies of DMSP transformation in the ocean? In an intensive study of a coccolithophore bloom in the North Sea, Archer et al. (2002) studied DMSP consumption in a Lagrangian experiment and found that bacteria were rapidly turning over DMSP. But during the time course of the experiment, the bacterial assemblage became dominated by Rosebacter species (Zubkov et al., 2002) as well as members of the gammaproteobacterial SAR86 cluster and a Bacteroidetes cluster. SAR11 did not bloom, though DMSP production was high. Thus, it appears that increasing the supply of sulphur-containing compounds, such as DMSP, is unlikely to lead to a high biomass of 'Cand. P. ubique' in the sea. DMPS may supply sulphur compounds, but something else may be limiting growth and preventing the development of dense 'Cand. P. ubique' populations. This is consistent with what is known from cultures, which remain as dilute cell suspensions. Something else appears to limit the development of high cell densities.

The findings of Tripp et al. (2008) provide an additional insight into SAR11, but many puzzles remain. Despite high levels of 16S rRNA gene sequence similarity, SAR11 could actually be a diverse group of organisms, adapted to a wide range 
of marine habitats. In a study of nine strains isolated from a single $2 \mathrm{l}$ water sample, Vergin et al. (2007) found that recombination was prevalent in SAR11, suggesting that recombination may be important in the adaptive diversification of this group. It may be possible that SAR11 isolates from different marine provinces will prove to have considerable differences in physiology. Unfortunately, there is still a shortage of cultures to allow meaningful physiological analysis to complement genomic comparisons. The few cultures that exist do not provide the biomass that is required to determine physiology. Culture-independent methods have also proved disappointing for revealing the secrets of SAR11. For example, it is surprising that in an analysis of $>50000$ fosmids, DeLong et al. (2006) found no 16S rRNA sequences for SAR11 in the surface $500 \mathrm{~m}$. The most abundant species in the ocean might have been expected to occur at a higher frequency in such fosmids libraries.

The analysis by Tripp et al. (2008) serves to reveal a bit more about the enigma of SAR11. However, we are still some way from answering basic questions about the diversity of this clade, and how these organisms can apparently be so successful that they dominate the bacterioplankton of many diverse marine provinces.

\section{Joint is at Plymouth Marine Laboratory, Prospect Place, The Hoe, Plymouth, UK E-mail: irj@pml.ac.uk}

\section{References}

Archer SD, Gilbert FJ, Nightingale PD, Zubkov MV, Taylor AH, Smith GC et al. (2002). Transformation of dimethylsulphoniopropionate to dimethyl sulphide during summer in the North Sea with an examination of key processes via a modelling approach. Deep-Sea Res II 49: 3067-3101.

DeLong EF, Preston CM, Mincer T, Rich V, Hallam SJ, Frigaard N-U et al. (2006). Community genomics among stratified microbial assemblages in the ocean's interior. Science 311: 496-503.

Giovannoni SJ, Britschgi TB, Moyer CL, Field KG. (1990). Genetic diversity in Sargasso Sea bacterioplankton. Nature 345: 60-63.

Giovannoni SJ, Tripp HJ, Givan S, Podar M, Vergin KL, Baptista D et al. (2005). Genome streamlining in a cosmopolitan oceanic bacterium. Science 309: 1242-1245.

Mary I, Heywood JL, Fuchs BM, Amann R, Tarran GA, Burkill PH et al. (2006). SAR11 dominance among metabolically active low nucleic acid bacterioplankton in surface waters along an Atlantic meridional transect. Aquat Microb Ecol 45: 107-113.

Morris RM, Rappé MS, Connon SA, Vergin KL, Siebold WA, Carlson CA et al. (2002). SAR11 clade dominates ocean surface bacterioplankton communities. Nature 420: 806-810.

Rappé MS, Connon SA, Vergin KL, Giovannoni SJ. (2002). Cultivation of the ubiquitous SAR11 marine bacterioplankton clade. Nature 418: 630-633.

Tripp HJ, Kitner JB, Schwalbach MS, Dacey JWH, Wilhelm LJ, Giovannoni SJ. (2008). SAR11 marine bacteria require exogenous reduced sulphur for growth. Nature (in press).

Vergin KL, Tripp HJ, Wilhelm LJ, Denver DR, Rappé MS, Giovannoni JJ. (2007). High intraspecific recombination rate in a native population of Candidatus pelagibacter ubique (SAR11). Envir Microbiol 9: 2430-2440.

Zubkov MV, Fuchs BM, Archer SD, Kiene RP, Amann R, Burkill PH. (2002). Rapid turnover of dissolved DMS and DMSP by defined bacterioplankton communities in the stratified euphotic zone of the North Sea. Deep-Sea Res II 49: 3017-3038. 